\title{
Spawning and Fecundity of Two Types of Hilsa ilisha in Bangladesh Waters*1
}

\author{
Miah Muhammed Abdul Quddus, ${ }^{* 2}$ Makoto Shimizu,*3 \\ and Yukio NosE*3 \\ (Accspted May 10, 1983)
}

\begin{abstract}
The study of spawning, fecundity and sex ratio of two types (A and B) of Hilsa ilisha showed that they had different breeding seasons, i.e., type A from July to October and type B from January to March. Spawning season was determined from gonadosomatic indexes and the peak spawning occurred in September for A and February for B type. Fecundity was found to range from 660 to 1547 thousand for fish between 342 to $520 \mathrm{~mm}$ of type $\mathrm{A}$ and 399 to 670 thousand for fish between 260 to $470 \mathrm{~mm}$ in total length of type B, and observed to be related to total length, body weight, gonad weight and age of the fish. Regarding the sex ratio of type $A$, the females were preponderant in the months of October and December whereas the males were preponderant in June, but in the case of type B, it was observed to be $1: 1$.
\end{abstract}

In the previous papers, we reported on the occurrence of two types of Hilsa ilish ${ }^{1)}$ and also the results of the age determination and their differences in growth. ${ }^{2)}$ As already stated, ${ }^{1)}$ conflicting opinions were expressed by a number of workers regarding its migration and spawning season. This paper presents the results of the investigation on some reproductive characteristics of the two types of Hilsa ilisha.

\section{Materials and Methods}

Samples are the same as those utilized in the previous study. ${ }^{1)}$ To find out the gonadosomatic index (GSI) for the determination of spawning season, the body weight and gonad weight of both male and female as well as their ratio in percentage were recorded monthwise for both the types $\mathrm{A}$ and B separately, using the formula:

$$
\text { GSI }=\frac{\text { Gonad weight }}{\text { Body weight }} \times 100 \text {. }
$$

For fecundity estimation gravid females were collected. Eye observation and common experience were used to identify them. The specimen were chosen carefully so that only matured but unspawned fishes of different length and weight were taken.
Fecundity estimation was done by counting the ova of 27 specimens of type $A$ and 12 of type $B$, which were collected from the river Padma near Goalnando during their spawning seasons, the Monsoon for type A and late winter for type B.

The two lobes of an ovary from each specimen were carefully removed and preserved in $5 \%$ formalin to permit hardening of ova to facilitate the counting. To estimate the fecundity, gravimetric or weight method was used.

\section{Results}

The female fish which was about to spawn was much more pot-bellied than the male. The enlarged abdomen of the female was quite soft to touch. No specimen showed any evidence of having spawned before they were collected for fecundity estimation. There was no noticeable difference between the right and left ovaries.

\section{Gonadosomatic Index}

The gonadosomatic index values in winter of type $A$ were $2.20 \pm 0.38$ and $0.15 \pm 0.04$ for female and male, and in Monsoon $10.3 \pm 1.37$ and 0.53 \pm 0.09 for female and male, respectively. A marked increase (especially in female) from the

*1 This paper is based on part of a thesis submitted for the award of degree of Doctor of Agricultural Science, University of Tokyo.

*2 Department of Zoology, Dhaka University, Dhaka, Bangladesh. (M. M. A. クドゥス ダッカ大学動物 学科).

*3 Department of Fisheries, Faculty of Agriculture, University of Tokyo. Yayoi, Bunkyo, Tokyo 113, Japan (清水 誠・能勢幸雄: 東京大学紫学部水産学科). 


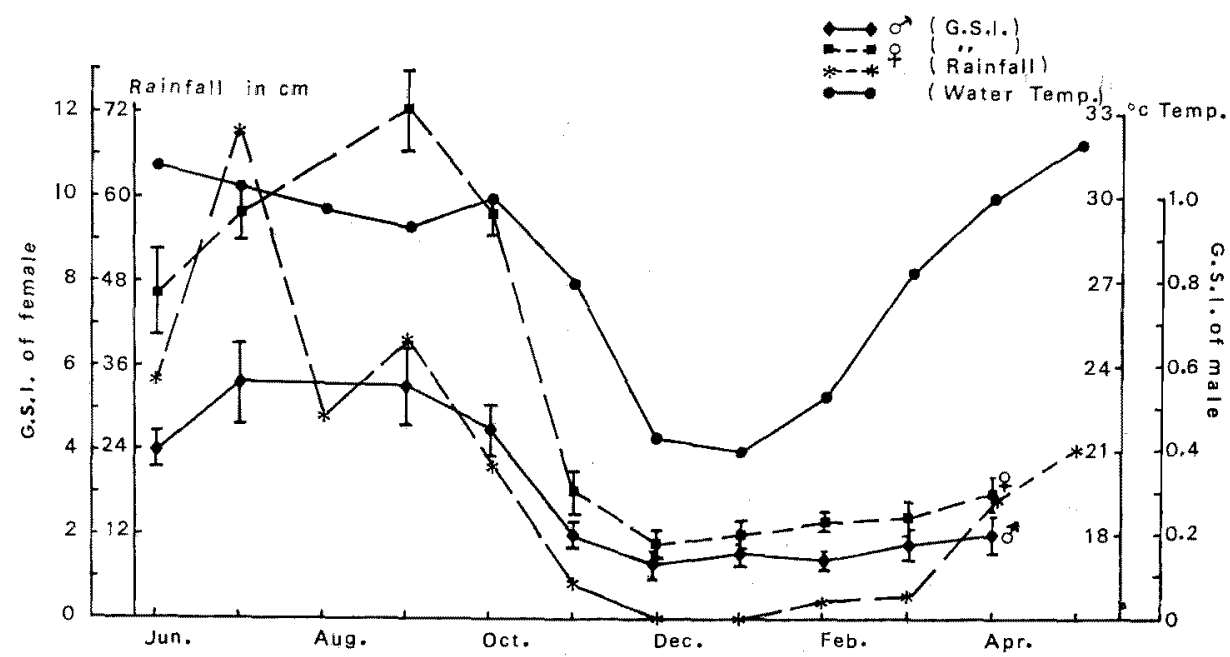

Fig. 1. Seasonal fluctuations of gonadosomatic index (with standard deviation) of male and female of type A with water temperature and rainfall.

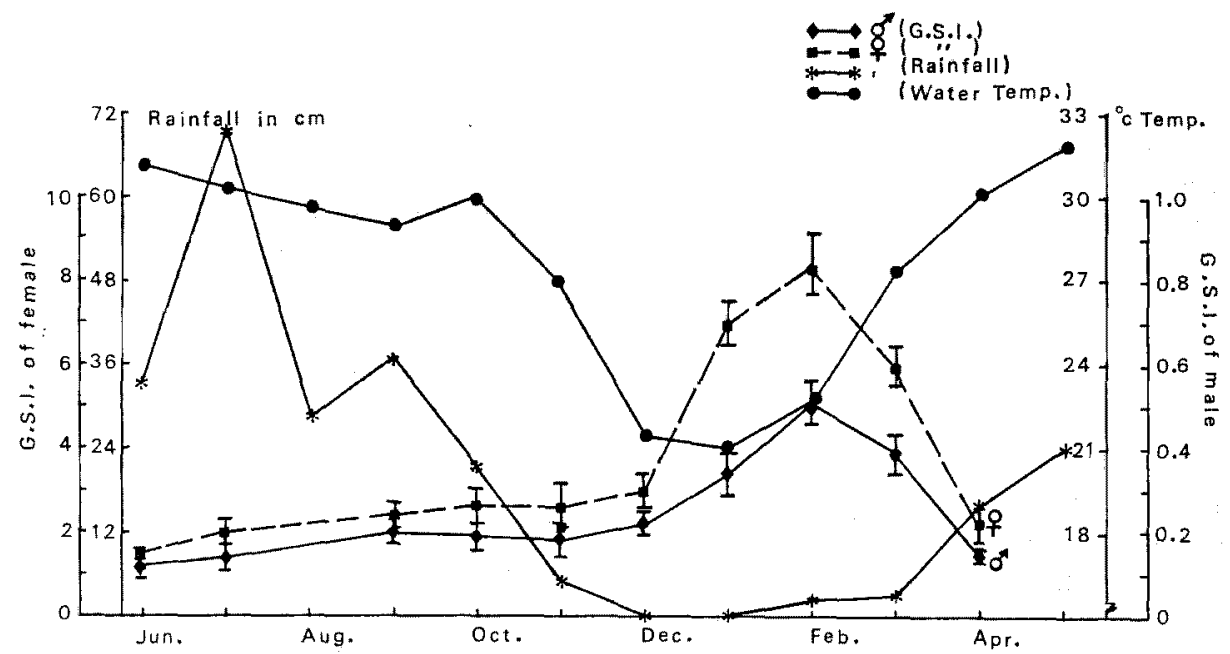

Fig. 2. Seasonal fluctuations of gonadosomatic index (with standard deviation) of male and female of type B with water temperature and rainfall.

month of June to October, with a peak in September, may be due to completion of maturity and that of spawning season. A sudden fall was indicated in the GSI value in November to February probably due to post spawning period. A gradual increase of GSI value was found from March to June may be prespawning season (Fig. 1).

The GSI values of type B were $7.25 \pm 1.26$ in winter for the female and $0.43 \pm 0.09$ for the male. In the Monsoon $2.40 \pm 0.45$ for the female and $0.17 \pm 0.04$ for the male. In this case also a marked increase was shown in GSI (especially for the female) from the month of December to March with a peak in February, possibly due to completion of the spawning season. A sudden fall in GSI value from April to November was also noted and it was probably due to the post spawning season (Fig. 2).

\section{Spawning Process}

To get some indications of the spawning process, 10 ova were taken at random from the anterior, middle and posterior parts of the left and right lobes of the ovary. Their mean diameter showed no significant difference among the locations in the ovary at $5 \%$ level, possibly indicating 
Table 1. Comparative relationship of ovary weight and fecundity parameters of types A and B, Hilsa ilisha

\begin{tabular}{|c|c|c|c|c|c|c|c|c|c|c|c|}
\hline $\begin{array}{l}\text { Comparison of } \\
\text { types } A \text { and } B\end{array}$ & & $N$ & $\left(S^{\bar{x}} \mathrm{D}\right)$ & $\left(\mathrm{S}^{\bar{y}} \mathrm{D}\right)$ & $a$ & $b$ & $r$ & $F_{0}$ & FR & $\begin{array}{c}\text { FB } \\
\text { (d.f.) }\end{array}$ & $\begin{array}{l}\text { FM } \\
\text { (d.f.) }\end{array}$ \\
\hline $\begin{array}{l}\text { Total length } \\
\text { and } \\
\text { ovary weight }\end{array}$ & A & 12 & $\begin{array}{l}416.3 \\
(60.6) \\
401.3 \\
(60.9)\end{array}$ & $\begin{array}{r}84.8 \\
(29.9) \\
42.8 \\
(16.0)\end{array}$ & $\begin{array}{r}-107.1 \\
-50.9\end{array}$ & $\begin{array}{l}0.461 \\
0.233\end{array}$ & $\begin{array}{l}0.935 \\
0.889\end{array}$ & $\begin{array}{r}173.8^{* *} \\
37.6^{* *}\end{array}$ & 1.25 & $\begin{array}{l}2.13 \\
(1,35)\end{array}$ & $\begin{array}{l}53.1^{* *} \\
(1,36)\end{array}$ \\
\hline $\begin{array}{l}\text { Body weight } \\
\text { and } \\
\text { ovary weight }\end{array}$ & A & 12 & $\begin{array}{c}822.3 \\
(328.1) \\
709.3 \\
(240.5)\end{array}$ & $\begin{array}{r}84.8 \\
(29.9) \\
43.6 \\
(16.2)\end{array}$ & $\begin{array}{r}14.2 \\
-1.8\end{array}$ & $\begin{array}{l}0.86 \\
0.064\end{array}$ & 0.943 & $\begin{array}{l}199.5^{* *} \\
89.4^{* *}\end{array}$ & 2.21 & $\begin{array}{l}5.89^{*} \\
(1,35)\end{array}$ & $\begin{array}{c}153.9^{* *} \\
(1,36)\end{array}$ \\
\hline $\begin{array}{l}\text { Age and } \\
\text { ovary weight }\end{array}$ & B & 12 & 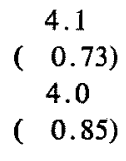 & $\begin{array}{c}84.8 \\
(29.9) \\
42.8 \\
(16.0)\end{array}$ & $\begin{array}{l}-66.1 \\
-22.9\end{array}$ & $\begin{array}{l}37.051 \\
16.441\end{array}$ & 0.876 & $33.1^{* *}$ & 2.61 & $\begin{array}{l}0.009 \\
(1,35)\end{array}$ & $\begin{array}{l}98.9^{* * *} \\
(1,36)\end{array}$ \\
\hline $\begin{array}{l}\text { Total length }(\mathrm{mm}) \\
\quad \text { and } \\
\text { fecundity }\left(10^{9}\right)\end{array}$ & $\begin{array}{l}\text { A } \\
\text { B }\end{array}$ & 27 & $\begin{array}{l}416.3 \\
(60.6) \\
401.3 \\
(60.9)\end{array}$ & $\begin{array}{c}973.7 \\
(251.9) \\
535.9 \\
(89.6)\end{array}$ & $\begin{array}{r}-660.5 \\
-14.6\end{array}$ & $\begin{array}{l}3.925 \\
1.372\end{array}$ & $\begin{array}{l}0.944 \\
0.933\end{array}$ & $\begin{array}{l}204.4^{* *} \\
67.6^{* *}\end{array}$ & 1.69 & $\begin{array}{r}10.8^{* *} \\
(1,35)\end{array}$ & $\begin{array}{c}283.4^{* * *} \\
(1,36)\end{array}$ \\
\hline $\begin{array}{l}\text { Body weight (g) } \\
\quad \text { and } \\
\text { fecundity }\end{array}$ & A & 27 & $\begin{array}{l}822.3 \\
(328.1) \\
709.3 \\
(240.5)\end{array}$ & $\begin{array}{r}973.7 \\
(251.9) \\
535.9 \\
(89.6)\end{array}$ & 382.9 & 0.718 & $\begin{array}{l}0.935 \\
0.953\end{array}$ & $\begin{array}{l}174.9^{* * *} \\
99.3^{* *}\end{array}$ & 2.57 & $\begin{array}{l}6.76^{*} \\
(1,35)\end{array}$ & $\begin{array}{c}277.4^{* * *} \\
(1,36)\end{array}$ \\
\hline $\begin{array}{l}\text { Ovary weight (g) } \\
\quad \text { and } \\
\text { fecundity }\end{array}$ & $\begin{array}{l}\text { A } \\
\text { B }\end{array}$ & 27 & $\begin{array}{c}84.8 \\
(29.9) \\
42.8 \\
(16.0)\end{array}$ & $\begin{array}{r}973.7 \\
(251.9) \\
535.9 \\
(89.6)\end{array}$ & 296.1 & 7.987 & 0.947 & $\begin{array}{l}217.8^{* *} \\
123.4^{* *}\end{array}$ & 1.96 & $\begin{array}{r}24.2^{* * *} \\
(1,35)\end{array}$ & $\begin{array}{l}20.1^{* *} \\
(1,36)\end{array}$ \\
\hline $\begin{array}{l}\text { Age and } \\
\text { fecundity }\end{array}$ & B & 27 & 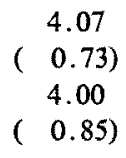 & $\begin{array}{r}973.7 \\
(251.9) \\
535.9 \\
(89.5)\end{array}$ & -226.0 & 294.467 & 0.853 & $66.7^{* *}$ & 1.82 & $\begin{array}{l}8.89 * * \\
(1,35)\end{array}$ & $\begin{array}{c}156.2^{* * *} \\
(1,36)\end{array}$ \\
\hline
\end{tabular}

$a=$ intercept, $b=$ slope, $r=$ correlation coefficient, $F O=$ test of linear relationship, $F R=$ test of homogenetty of variance, $F B=$ test of slope, FM = test of adjusted mean, d.f. = degrees of freedom. * significant at $5 \%$ lelel, ** significant at $1 \%$ level.

that the ova matured and were released simultaneously in both the lobes irrespective of their locations in the ovary.

To have a comparative relationship between ovary weight with total length, body weight, and age of types $\mathbf{A}$ and $B$, regression analysis was performed and it was found to be linear. The analysis of covariance showed a significant difference between types $\mathrm{A}$ and $\mathrm{B}$ (Table 1).

\section{Fecundity}

Hilsa ilisha is a highly fecund fish, and variations were found in the fecundity of equal and subequal size or weight within types $A$ and $B$. The estimated number of ova produced by a specimen of type A, ranged from 660 thousand (for a fish with a total length of $342 \mathrm{~mm}$, a body weight of $465 \mathrm{~g}$ and an ovary weight of $51 \mathrm{~g}$ ) to 1547 thousand (for a fish with a total length $520 \mathrm{~mm}$, a body weight of $1750 \mathrm{~g}$ and an ovary weight of $148 \mathrm{~g}$ ). In the case of type B, it ranged from 399 thousand (for a fish with a total length of $260 \mathrm{~mm}$, a body weight of $310 \mathrm{~g}$ and an ovary weight of $16 \mathrm{~g}$ ) to 670 thousand (for a fish with a total length of $470 \mathrm{~mm}$, a body weight of $1000 \mathrm{~g}$ and an ovary weight of $65 \mathrm{~g})$.

To find the comparative relationship of fecundity with total length, body weight, ovary weight and age of types $A$ and $B$, the regression analysis was conducted and it was observed to be linear (Figs. 3 and 4). Covariance analysis was also conducted for comparison which showed a significant difference existed between types A and B (Table 1).

\section{Sex Ratio}

To find out whether males and females are equally distributed or not the difference between observed and expected ratio $(1: 1)$ were examined by 


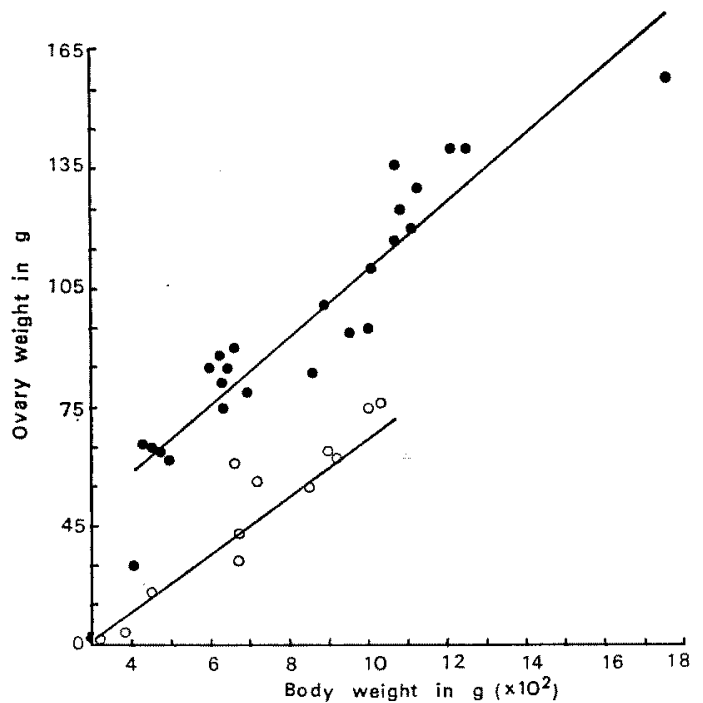

Fig. 3. Relationship between body weight $(X)$ and ovary weight (Y) of type $A, Y=14.243+0.086 \mathrm{X}$ (Solid circle) and type $B, Y=-1.829+0.06 \mathrm{X}$ (Open circle).

the chi-square test. These tests were carried out each month and for an annual average for both the types $\mathrm{A}$ and $\mathrm{B}$.

In the case of type $A$, it was observed that females were preponderant in the month of October $\left(\chi^{2}=4.84\right)$, December $\left(\chi^{2}=5.48\right)$ and in grand average $\left(\chi^{2}=5.54\right)$ where as males were preponderant only in June $\left(\chi^{2}=7.20\right)$. In the case of type $B$ either monthwise or in the annual average, the sex ratio was not significantly different from the expected ratio of $1: 1$ and it was found to be the same in Monsoon as well as in winter.

\section{Discussions}

Conflicting opinions exist regarding the spawning of Hilsa ilisha. GHOSH and NANGPAL ${ }^{3)}$ considered that the winter breeder is a "resident" variety which breeds from late February to early March influenced by water temperature, current velocity and standing crops of planktons. This resident variety does not migrate to the sea and they are similar to the "slender" variety, one of the subpopulations stated by GHosH et al..$^{4)}$ Moreover, Hilsa ilisha inhabits widely separated zones in India and lives under diverse ecological conditions. There are possibilities that it comprises several races capable of living and breeding under different environmental conditions. ${ }^{5)}$ On the other hand, $\mathrm{JOB}^{(\theta)}$ considered that the breeding period is slightly variable from place to place on account of different

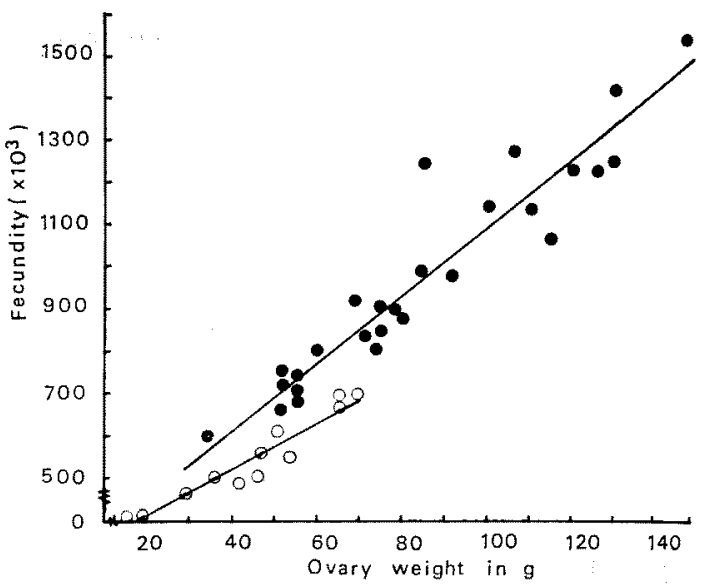

Fig. 4. Relationship between ovary weight $(X)$ and fecundity $(Y)$ of type A, $Y=296.101+7.987$ (Solid circle) and type B, $Y=305.660+5.383 \mathrm{X}$ (Open circle).

ecological conditions. In the present investigation it is observed that Hilsa ilisha breeds at two different times even in the same river, one for type $A$ and the other for type $B$.

KulKarNi, ${ }^{7}$ and BhuIYAN and TAlBot $^{8)}$ observed in the rivers Godavari and Indus a single breeding season. Pillay, ${ }^{\text {B) }}$ on the other hand, described two breeding seasons in the Hooghly River, one from the beginning of southwest Monsoon until November and the other from January to March. Motwant et al ${ }^{18)}$ reported a prolonged breeding season in the Ganges River, which appears to commence with the onset of the Monsoon in July. SHafI et al. ${ }^{11)}$ in their studies on the limnology of the River Meghna observed that rainfall was nearly nil and water temperature low from December to February, and from March onwards both temperature and rainfall gradually increased. On the other hand, during the Monsoon from July to October, both temperature and rainfall kept the higher values. Besides the plankton production of the River Meghna showed bimodal curves, presenting two maxima, one in May and the other in October and two minima, one in August and the other in January.

From these observations, it might be assumed that in the Monsoon and in winter months availability of plankton is high in the river system which affords favourable conditions for breeding and feeding of young of both the types.

The fecundity of Hilsa ilisha is quite high in the rivers Hooghly, ${ }^{\text {?) }}$ Godavari, ${ }^{11)}$ Narbada, ${ }^{7}$ Indus, Padma, ${ }^{13)}$ and Meghna. ${ }^{14}$ The present study also shows the similar result. 
DoHA and Hye, ${ }^{19)}$ Shafi et al.$^{21)}$, SAWruP, ${ }^{13)}$ Pillay, ${ }^{9)}$ and PIILAY and RaO ${ }^{10}$ ) observed linear relationship between fecundity with length, weight and egg diameter but BHUTYAN and TALBOT $^{8}$ ) observed no close relationship between length, weight and fecundity. In the present study, relationships between fecundity with length, weight, ovary weight and age were examined and it was found that there was a linear relationship existing within both types and also a marked difference between types $\mathbf{A}$ and $\mathbf{B}$.

The sex ratio of type $B$ was observed to be $1: 1$ every month and season in the rivers Padma and Meghna. Similar observations were also reported by Pillay and RaO, ${ }^{16)}$ MAThur, ${ }^{17)}$ Shafi et al.$^{14}$ and RAJYALAKSHMI, ${ }^{18)}$ In the case of type $A$, the females were preponderant in October and December whereas the males in June. But in all other months, the ratio was not significantly different from the expected ratio of $1: 1$. Similar differences were observed by KARAMCHANDANI, ${ }^{103}$ Chacko and Ganapatr, ${ }^{12)}$ and SaWrup. ${ }^{15)}$

\section{References}

1) M. M. A. Quddus, M. Shimizu, and Y. Nose: Bull. Japan. Soc. Sci. Fish. 50: 43-49 (1984).

2) M. M. A. Quddus, M. Shimizu, and Y. Nose: Bull. Japan. Soc. Sci. Fish. 50: 51-57 (1984).
3) A. N. Ghosh, T. D. Nangpal: Proc. IndoPacif. Fish. Coun., 13, 132-142 (1968).

4) A. N. Ghosh, R. K. Bhattachariya, and K. V. RAO: Proc. Nat. Inst. India, 34, 44-59 (1969).

5) J. T. Jenkins: Curr. Sci., 9, 241-242 (1940).

6) J. T. Јов: Sci. and Cult., 7, 427-429 (1942).

7) C. V. Kulkarni: Proc. Nat. Inst. Sci. India. 15, 176-196 (1950).

8) N. I. Bhutyan and G. B. Talbot: Trans. Amer. Fish. Soc., 97, 350-355 (1968).

9) T. V. R. Prllay: Indian J. Fish., 5, 201-257 (1958).

10) M. P. Motwani, V. G. Jhingran, and S. J. Karamchandan: Sci. and Cult., 23, 47-48 (1957).

11) M. Shafi, M. M. A. Quddus, and M. N. Islam: Dhaka Univ. Stud., 26, 63-71 (1978).

12) P. I. Chacko and S. V. Ganapati: J. Madras Univ., 18, 16-22 (1949).

13) S. DoHA and M. A. HYE: Pak. J. Sci., 22, 176186 (1970).

14) M. Shafi, M. M. A. Quddus, and M. N. Islam: Asiat. Soc. Bangladesh (Sci.), 2, 51-58 (1977).

15) K. SawruP: Zool. Soc. India, 13, 108-112(1961).

16) S. R. Pillay and K. V. Rao: Proc. Indo-Pacif. Fish. Coun., 10, 37-61 (1962).

17) P. K. MAthur: Indian J. Fish., 11, 423-448 (1967).

18) T. Rajyalakshm: Indian J. Fish., 20, 78-94 (1973).

19) S. J. Karamchandani：Curr. Sci., 30, 383-375 (1961). 